\title{
From state control to network governance of primary education in Tanzania: has local empowerment been attained?
}

\author{
Orest Sebastian Masue (Corresponding author) \\ School of Public Administration and Management \\ Mzumbe University, PO Box 2, Mzumbe, Morogoro, Tanzania \\ Tel: 00255652614606; E-mail: osmasue@mzumbe.ac.tz \\ Idda Lyatonga Swai \\ School of Public Administration and Management \\ Mzumbe University, PO Box 2, Mzumbe, Morogoro, Tanzania \\ Tel: 00255783128049; E-mail: ilyatonga@mzumbe.ac.tz
}

Accepted: March 02, 2015

Doi:10.5296/ jpag.v5i1.7169 URL: http://dx.doi.org/10.5296/ jpag.v5i1.7169

\begin{abstract}
Governance networks have recently become popular and apparently indispensable in public administration especially due to the fact that we are operating in the context of complex, fragmented and multi-layered societies. The purpose of this theoretical paper is to (1) delineate the concept of governance in terms of its three distinct modes (state control, market and networks/pluralist modes), (2) show how governance of primary education in Tanzania has changed along these three modes of governance and (3) comment on whether the change in the mode of governance of Primary Education in Tanzania from state control to governance networks has led to empowerment of the people at the grassroots levels. Our observation in this paper is that the move from the state control to network governance mode is too theoretical, and has not sufficiently led to empowerment of people at the grassroots levels in the governance of primary education. Therefore, this paper calls upon the state to willingly change radically from its culture from hierarchical control to authentic local empowerment.
\end{abstract}

Keywords: Governance, Empowerment, State control, Market mode, Networks governance 


\section{Introduction}

The term governance is broad and its usage in the literature is "multi-dimensional" to the extent that it often runs short of "operational precision" (Quibria, 2006:102; Rhodes, 1996). The broadness and vagueness of the concept are attributed not only to the huge variance of its usage contexts but also the diversity of researchers in the field (O'Toole, 2000; Peters \& Pierre, 1998).

Literary, governance can be regarded as "the act of governing" or "steering" the process that influence decision making and action in the public and/or private sector (Emerson, et.al 2006:2; O‘Leary, et al 2006:7; Pal, 2012). It focuses not only on the government but on the entire 'apparatus' embedding both governmental and non-governmental organizations in steering the process of solving shared problems on public interest (Pal, 2012). Therefore, governance can be regarded as a collaborative action whereby actors in the public sector and those outside it (i.e.in the private sector, NGOs and civil societies) jointly contribute efforts to accomplish of a public goal. The traditional literature views governance as synonymous to government. In the contrary, the contemporary literature views governance and government as two different concepts based on their approach of governing. While the government governs through bureaucratic/hierarchical approach, governance employs horizontal/non-hierarchical approach where non-state actors participate in decision making and implementation, and also service delivery (Rhodes, 2008; Mayntz, 2003; Rhodes, 1997; Sørensen \& Torfing, 2007).

\subsection{Governance and governance network $(s)$}

Governance involves a complex art of steering several agencies, institutions, actors or systems that are operationally autonomous from each other yet structurally coupled together due to their mutual interdependence (Jessop 2002; Rhodes, 1997; Sørensen \& Torfing, 2005). Governance often operates in networks which comprise of organizations which have willingly decided to exchange resources (financial, informational, expertise and so on) to enable them realize mutual goals. The various kinds of collaboration through which different actors agree on to tackle common socio-economic problems or deliver service is called governance networks.

The concept of governance networks has different meanings depending on the context in which it is used. It is argued that governance network stems from the concept of multi-organisational cooperative actions for public service delivery (Klijn 2008; Provan \& Kenis, 2008) that attempts to respond to the inadequacy of the rigid bureaucratic top-down approaches in addressing the issues of inclusion of citizens and interest groups in decision making and service delivery (Ansell \& Gash, 2008). Through governance networks, decisions and service delivery are done through multi-actor relationships (networks) of public and non-public actors (such as private and voluntary organizations and civil societies). These relationships are usually characterized by high level of interdependency among the actors and pluralistic/complex decision making processes (Klijn et al, 2010).

The concept of governance networks can also be conceptualised in Emerson et al (2012)'s 
broad concept of collaborative governance; -

"...the processes and structures of public policy decision making and management that engage people constructively across the boundaries of public agencies, levels of government, and/or the public, private and civic spheres in order to carry out a public purpose that could not otherwise be accomplished"(Emerson, 2012:2).

In this definition, collaborative governance is more than formal, state-initiated governance arrangements and government and non-governmental stakeholder engagements. It can be regarded as a "multipartner governance" mode involving the state, the private sector, civil society, various community-based collaborative efforts and different levels of participatory governance and civic engagement in governance. This approach of governance can also incorporate Agrawal \& Lemos (2007)'s concept of joined-up government and hybrid arrangements such as public-private and private-social partnerships and co-management regimes (Ibd: 3).

In this paper, we use Sørensen and Torfing's (2005) definition and theoretical scope of governance network $(s)$ to explain what networked governance entails, its applicability to the Tanzanian primary education governance and whether governance networks empower the grassroots. By definition,

'Governance network' can be defined as a relatively stable horizontal articulation of interdependent, but operationally autonomous actors who interact through negotiations that involve bargaining, deliberation and intense power struggles which take place within a relatively institutionalized framework of contingently articulated rules, norms, knowledge and social imaginaries that is self-regulating within limits set by external agencies and which contribute to the production of public purpose in the broad sense of visions, ideas, plans and regulations (Sørensen \& Torfing, 2005:197).

From the definition, we get a picture that a network can be called a governance network if it to bears the following features:

First, it consists of heterogeneous actors (private, semi-public and public) who besides their operational autonomy, they are dependent on each other in order to get things done. They seek to organize themselves to accomplish an issue of public interest; be it policy making, policy implementation, solving a particular problem or service delivery. They have a stake in the issue at hand and are willing to contribute resources and competences of a certain value to the network (Jessop 2000). Network governance is thus characterized by inter-organizational linkages, shared interest and interdependence of actors. The number of actors in a network may vary considerably, but at least three actors may constitute a governance network.

Second, the decision making processes in the network are deliberative, involving negotiations, bargaining and power struggles among the actors, and no place for top-down/bureaucratic control. This is to say, relations between the actors in a network are horizontal rather than vertical. 
Third, they operate in agreed self- regulating framework of rules, regulations, norms and social beliefs to govern the behavior of individual actors in accordance with the limits of the state and international laws. Governance networks have a broader scope than that of a traditional government. Through self-organizing networks, services are provided by a combination of government, private and voluntary sectors (Rhodes 1996).

\subsection{Forms of governance networks}

Governance networks are diverse and can take various empirical forms in different countries at different levels of governance and within various policy areas (Torfing, 2006). For simplicity, governance networks can be classified on the basis of their origin, type of contacts /relationships, relationship domain, life span and scope or coverage (table 1). On the basis of these criteria, governance networks can be distinguished as: - self-grown networks vs. those initiated from above, loosely coupled vs. tightly coupled networks, intra-organizational vs. inter-organizational networks, short-lived vs. permanent networks, and sector-specific vs. society-wide networks. In addition, some networks are open and inclusive, allowing new actors to join with minimal restriction; while others are closed and exclusive for certain defined actors. With regard to scope or coverage, some governance networks pursue broad society-wide policy goals, while others have a narrow scope, focusing on single issues. In the same dimension, some networks confine themselves to knowledge sharing, agenda setting, or policy formulation, while others focus on implementation of policy. These distinctions indicate that governance networks are diverse and hence, different typologies have been constructed (Klijn et al 1997; Marsh \& Rhodes, 1992). We will elaborate a little bit on these distinctions.

\subsubsection{Self-grown networks vs. those initiated from above}

While some governance networks are formally organized and mandated from above, others are informally organized and relatively self-grown/self-organized (Huppé, 2012; Sørensen \& Torfing, 2005).

Self-grown networks are informally organized and self-mandated to accomplish self-organized activities (Sørensen \& Torfing, 2009), while formal networks are those officially set up by some convening body where membership may either be coerced or have some compelling normative or resource incentives to participate (Isett, et al 2011). This kind of networks seek to accomplish activities determined by higher organs, for example, a network of Local Government Authorities (municipalities) working together to accomplish the goals set by the Central Government pertaining to education, health or environment in decentralized governance systems.

\subsubsection{Loosely-coupled vs. tightly-coupled networks}

A network can be regarded as being loosely- coupled or tightly- coupled depending on three major dimensions: first, the extent of interdependence of actors within in the network, that is, the strength of linkages between network actors; second, distinctiveness of actors in the network, that is, the degree to which individual actors are well defined and semi-autonomous; and third, integration- the degree of coordination seen in interaction 
patterns between network actors (Orton \& Weick, 1990; Pinelle \& Gutwin, 2005).

Loose coupling of governance networks exists when the level of interdependence between actors is low, and actions of individual elements affect the other elements weakly or infrequently. Loosely-coupled networks are also characterized by high differentiation and low integration. Actors are distinct, logically separate, and independent Interaction to manage interdependence between actors takes at place irregular occasions (Kang, 2012; Orton \& Weick, 1990; Pinelle \& Gutwin, 2005). Tightly-coupled networks on the other hand have high interdependence, low differentiation and high integration. Each actor's actions affect the other actors in the network significantly and frequently. Actors are indistinct and dependent on one another, with continual interaction.

\subsubsection{Intra-organization vs. inter-organization networks}

In the era of globalization, many organizations are adopting network structures (both intra and inter-organizational) as the means for improving efficiency and effectiveness. Intra-organization can be explained as 'networks within organizations'. This kind of networks are usually established by units of a multi-unit organization to facilitate knowledge transfer between units of the same organization to enhance innovation and performance; while inter-organizational networks as networks between organizations geared towards pooling different knowledge and skills to meet complex challenges, and they can either be within a single government jurisdiction or across jurisdictions, sectors, or levels of government (Dawes, Cresswell, \& Pardo, 2009; Hoberecht, 2011; Koliba et al 2011; Tsai, 2001et. al 2011). Intra-organizational networks take the form of a coordinated process of knowledge transfer and resource sharing in an organization in which various units mutually learn from among themselves and cooperate in a systems manner. This kind of social-contextual linkage (network) among the various organizational units nurtures development of new knowledge and innovation hence improves organizational effectiveness and efficiency (Tsai, 2001).

It has become evident that no single agency, organization, or sector can solve complex problems (such as poverty, political unrest, crime, global warming, greenhouse gases, education, and health) effectively and efficiently unless they converge into inter-organizational configurations (networks) that can provide large- scale solutions to this kind of problems. Inter-organization network concept recognizes that sustainable socio-economic development requires a multi- organizational collaboration to join-up efforts (material, knowledge and skill resources) to meet complex challenges. As Dale puts it; “...when faced with large-scale, complex problems, multiple organizations and institutions must join together to form a 'meta-organization' capable of developing the large-scale solutions needed to solve complex problems." [Dale Ainsworth (2011) cited in Hoberecht et al (2011:23)]. Intra and inter-organizational networks take advantage of the resource capacity synergy resulting from collaboration to solve some of the more wicked problems facing organizations and societies in general. In this view, it can go without saying that both intra-organizational and inter-organizational networks are increasingly becoming recognized as pivotal enabling structures for advancement of innovation, improved service delivery, spread risks, and mutual accountability. 


\subsubsection{Short-lived vs. permanent networks}

On the basis of life span, governance networks can be short-lived or permanent. While short-lived governance networks are more or less temporary in nature, permanent networks have comparatively enduring relations, and the forms of interaction between actors who strive to realize common gains are usually regular and frequent (Börzel, 1997). In permanent networks, actors adhere to regularized forms of cooperation, as opposed to the temporary/short-lived (also referred to as 'ad-hoc networks') which have more or less irregular and infrequent contacts (MacLeod \& Park, 2011). They are formed to pressure specific socio-economic targets in specific contexts such as policy formulation, constitutional change and so on. Temporary/short-lived networks can also form to respond to ad-hoc problems such as natural disasters (floods, tsunami, etc.) and after settling the situation, the network disintegrates or remains dormant. Due to their long-term coalition, actors in permanent networks tend to accumulate capacity in resources, skills, knowledge and experience compared to short-lived networks. Over time, networks undergo the processes of formation (i.e. actors getting together, agreeing on common goals and norms); struggle for stability (gaining legitimacy and skill development by the participants); routinization (internalization of the norms/rules); and network extension/growth which involves forging of new linkages with other networks or registering new members into the network. This can be interpreted as a maturing process through which the operational efficiency of the network increases as relations are established, psychological contracts are nurtured, and first conflicts are confronted (Jacobsen, 2012; Mandell \& Keast, 2008). These processes can typically be seen in international and regional co-operations such as the UN, EU and the AU.

\subsubsection{Sector-specific vs. society-wide governance networks}

There is nothing very new in this category of governance network distinctions. Rather, it is the network scope that makes the difference. In sector- specific networks, actors (units) in a specific sector form a network e.g. education sector network in Tanzania which involves various units in the Ministry of education, Regions, Districts and the schools working together to implement the universal primary education (UPE) policy. Sector-specific governance networks can also involve Multi-level / inter-governmental cooperation across country boundaries.

Society-wide networks cover multiple sectors/issues across the society, for example, environmental management (for instance pollution control) where actors from different sectors are involved. By incorporating actors from various sectors, networks create avenues for learning and effective governance. The challenges currently facing environmental management involve complexities and uncertainties inherent to environmental and sustainably, hence network governance with a multi-sector and transnational approach can work more successfully in addressing the complexities (Newig, 2010). 
Table 1: Distinctions/forms of governance networks - a summary

\begin{tabular}{|c|c|}
\hline Classification criteria & Types/forms of governance networks \\
\hline 1. Origin / initiation of the network & $\begin{array}{l}\text {-Self-grown networks: informally organized and } \\
\text { self-mandated (e.g. NGOs, civil societies and other } \\
\text { voluntary groups) } \\
\text {-Networks initiated from above: formally organized and } \\
\text { mandated from above (e.g. intra-ministerial network of } \\
\text { the units of the ministry of education in Tanzania) }\end{array}$ \\
\hline 2. Linkages, distinctiveness and integration of actors & $\begin{array}{l}\text { - Loosely coupled/informal networks : informal, flexible } \\
\text { relationships (e.g. networks of local NGOs addressing } \\
\text { different social issues) } \\
\text {-Tightly coupled/formal networks: formal, tight } \\
\text { relationships (e.g. local intra-ministerial networks, the EU) }\end{array}$ \\
\hline 3.Domain of interaction of actors in the network & $\begin{array}{l}\text {-Intra-organizational networks: relationships are between } \\
\text { sub-units (e.g. divisions, departments and sections) within } \\
\text { an organization. } \\
\text { - Inter-organizational networks }\end{array}$ \\
\hline 4. Life span of the network & $\begin{array}{l}\text {-Short-lived networks: short-term outcomes (solving a } \\
\text { particular problem or accomplishing a particular } \\
\text { mission/task). } \\
\text {-Permanent networks: enduring outcomes e.g. the UN, AU, } \\
\text { EU }\end{array}$ \\
\hline 5. Scope/extensiveness of the network & $\begin{array}{l}\text { Sector- specific networks: actors in a specific sector form a } \\
\text { network e.g. education network involving various units in } \\
\text { the ministry of education. } \\
\text { Society-wide networks: cover multiple sectors/issues } \\
\text { across the society, for example, environmental } \\
\text { management where different sectors are involved. } \\
\text {-Interaction of actors is thus, multi-sectoral. }\end{array}$ \\
\hline
\end{tabular}

As we have pointed out in the beginning, the distinctions of governance networks cannot be that simple because overlapping of attributes among the distinctions is always the challenge. The demarcations between types/categories are really fuzzy, and can only be perceived as a continuum rather than a dichotomy. For example, with tightly-coupled vs. loosely coupled networks, there is no clear cut between what can be called a tightly-coupled network or a loosely-coupled network. This is based on the fact the degree of interdependence of actors within in the network, the distinctiveness of actors in the network and the degree of coordination of network actors is difficult to measure. Also, some networks can be selfinitiated (such as NGOs) but at the same time they can be mandated from above through state regulation and control by incentives. 
An inter-organization network can be tightly or loosely-coupled, and its tasks can be accomplished through intra-organizational networks of the actors (organizations) constituting it. The same with life-span and scope, it is not easy to precisely to differentiate between a short-lived and a permanent network. What the term permanent network entail and what exactly can be called a temporary or a short-lived network cannot be explained in crisp set terms. These methodological challenges imply complexities in understanding governance networks and their functionality. Despite the challenges however, these distinctions still serve as crucial schemas leading to our theoretical understanding of the nature of governance networks.

\section{State control, market regulation and pluralist (network) governance in the Primary Education in Tanzania}

In this part of the paper, we examine important trends in the governance of primary education delivery from the 1970s to date. In the course of doing so, we utilize the governance theory to explain the trends in governance and involvement of citizens and other actors in the delivery of primary education. We particularly attempt to categorize the trends as: the era of expansionary collective national thought (1974-1985), the era of growth of the economy collective national thought (1986 - 1994) and the era of income and non-income poverty collective national thought (1995 to date)(Galabawa, 2001:18).

Table 2: Governance networks vs. the state control and the market regulation

\begin{tabular}{|c|c|c|c|}
\hline \multirow{2}{*}{$\begin{array}{l}\text { Distinguishing } \\
\text { criteria }\end{array}$} & \multicolumn{3}{|c|}{ Modes of governance } \\
\hline & State control/government & Market regulation & Governance network \\
\hline $\begin{array}{l}\text { 2. Approach to } \\
\text { decision making }\end{array}$ & $\begin{array}{l}\text { Substantial rationality } \\
\text { - translate the substantial } \\
\text { political values of the } \\
\text { government into detailed } \\
\text { laws and regulations } \\
\text { implemented and enforced by } \\
\text { public administrators } \\
\text { (bureaucrats) }\end{array}$ & $\begin{array}{l}\text { Procedural rationality } \\
\text { - Relies on the invisible } \\
\text { hand that leads to a } \\
\text { Pareto-optimal allocation of } \\
\text { goods and services insofar } \\
\text { as the procedures ensuring } \\
\text { free competition are } \\
\text { carefully observed. }\end{array}$ & $\begin{array}{l}\text { Negotiation/normative } \\
\text { rationality } \\
\text {-decision making and regulation } \\
\text { of various issues are } \\
\text { accomplished through } \\
\text { negotiations /face-to-face } \\
\text { dialogue }\end{array}$ \\
\hline $\begin{array}{l}\text { 3. Means of } \\
\text { ensuring } \\
\text { compliance with } \\
\text { important } \\
\text { decisions }\end{array}$ & $\begin{array}{l}\text { Through legal sanctions } \\
\text {-imposed rules and norms } \\
\text { that are enforced by the state } \\
\text { govern compliance }\end{array}$ & $\begin{array}{l}\text { Fear of economic loss } \\
\text { - Market controlled rules } \\
\text { and norms govern } \\
\text { compliance. }\end{array}$ & $\begin{array}{l}\text { Trust \& political obligations } \\
\text {-self constituted rules and norms } \\
\text { govern compliance. }\end{array}$ \\
\hline
\end{tabular}


Through the lens of governance dimensions of state control, market regulation and governance networks (Emerson, et al 2012; Kersbergen \& Waarden, 2004; Sørensen \& Torfing, 2005) as summarised in table 2; we discuss some key characterizing features of each era and then culminate by examining governance networks that enhance citizen involvement and empowerment of the local levels (school committees and parents) in decision making and implementation as regards to education delivery and development of respective local primary schools.

\subsection{State control/hierarchical mode of governance}

State control practices hierarchical (unicentric) governance approach that takes place in a formalized domination - subordination relationship, and is based on the creation of "collectively binding prescriptions and proscriptions" (Lavenex \& Schimmelfennig, 2009:797; Tengku-Hamzah \& Adeline, 2011). This mode governance is characterized by top-down control and formalized procedures, where governing entities determine how policy should be conducted and implemented to achieve some centrally determined goals (Bell \& Hindmoor, 2011; Kooiman, 2003). In this mode of governance, the behavior of other participating actors is influenced by governing authorities in a formal and vertical /bureaucratic structure, often through sanctions (Sørensen \& Torfing, 2005). The hierarchical governance of society by the state is effected on the basis of a substantial rationality (Sørensen \& Torfing, 2004). Three key attributes characterize the state control mode of governance, namely: hierarchy, sovereignty of state and enforceable legislation. Hence, it is criticized for being too much bureaucratic (leading to unnecessary delays) and corruption. State control also involves big governments which lead to high operating costs and inefficiency in service delivery.

The state control mode of governing was prominent during the era of 'expansionary collective national thought' in Tanzania (1970s- 1985); where the state was the key player in all socio-economic development initiatives. This model shaped all service provision sectors including the primary education sub-sector. In 1974, Tanzania launched an ambitious plan for achieving Universal Primary Education (UPE) by 1977 (Kuder, 2005). Achievement of UPE plan was part and parcel of the collective national philosophy; therefore it was necessary to connect it with the national ideology and other socio-economic policies. Thus, the 1970s through 1980s was associated with implementation of Socialism and Self-Reliance policy launched in 1967 under the country's central ideology of Ujamaa (African socialism), and UPE initiative was the key vehicle to the country's destination of social economic transformation. The ESR policy was launched as follow-up of the aspirations articulated in the Arusha ${ }^{1}$ Declaration and it underscored the weaknesses of education system in place (Baganda, 2008). It stressed on the need for curriculum reform to foster acquisition of practical life skills as well as linking of education plans and practices with national socio-economic development and the world of work (Nyerere, 1967). Under the principles of Arusha Declaration, access to resources and social services such as primary education was to be regulated and controlled in a way that would allow equitable access by all Tanzanians

\footnotetext{
${ }^{1}$ A municipality in northern part of the country
} 
regardless of their socio-economic status, ethnicity, religion or gender (Baganda, 2008; Galabawa, 2001; Mbilinyi, 2003). The decentralization programme of 1972, the Education Act of 1978 (which led to the abolition Local Government Authorities in the same year) and UPE target enshrined in the Musoma ${ }^{2}$ Resolution of 1974 led to considerable success particularly in raising primary school enrolment rates to over 90 percent by the early1980s. The corresponding Net Enrolment Rates indicated that the number of children who were actually attending school those days was between 65 and 70 percent (Davidson, 2004); which is a clear indication that access to education by the poor was consistent with the intentions of the national policy of ensuring equitable and fair provision of education to all.

However, this 'success story' was immediately frustrated by internal weaknesses including among others, weak and inappropriate policies and poor governance (Davidson, 2004). The UPE plan was implemented without a proper strategy for allocation of investment. The process of transferring the investment management function of primary education to local control was not taken seriously. The traditional system of central management and implementation of UPE was hierarchical (top-down), and did not provide avenues for democratic governance where students/pupils, parents and teachers could participate fully in the decisions that affect them. In addition, external factors such as oil price shocks and deterioration of terms of trade (Baganda, 2008; Galabawa, 2001) impeded the implementation of UPE programme. During this period, the government was the sole provider of social services. Support received from international donors and agencies for assisting the implementation of UPE was very little. The economic crisis of 1970s to 1980s became the main challenge to UPE sustainability (Mmari, 2005), leading to considerable deterioration of the government capacity to finance social services.

Although significant access to primary education was evident through high enrolment rates and rising intake rates, there was marked low internal inefficiency.

\subsection{Market regulation mode of governance}

Market regulation (multicentric) mode of governance involves competition between formally autonomous actors rather than the result of hierarchical control or networked co-ordination. This mode of governance is governed by the neo-liberal principle of "less state and more market" ;to ensure an optimal allocation of private goods and help to regulate the production of public goods and services in a more proficient manner (Sørensen \& Torfing, 2004:5). Governance through anarchic market regulation builds on the principles of profit maximization and a procedural rationality; through which the common good is redefined as a Pareto-optimal allocation of values which is obtained through adherence of market procedures safeguarding free rivalry between producers and consumers (Netter \& Megginson, 2001; Sørensen \& Torfing, 2005). However, the increased reliance on market model of governance was criticized as being pronouncedly weak to the extent of failing to prevent instability. For instance the economic crisis of 2008-2009 in the United States financial institutions which spread elsewhere damaging a large part of the world's financial system was a result of leaving the market forces (free-market) to operate without state control (Kotz,

\footnotetext{
${ }^{2}$ A municipality in the lake Victoria zone in Tanzania
} 
2009).

The market mode of governance operated for the first time in Tanzania during the 'the era of growth of the economy collective national thought' (1986 - 1994). This is the period which was associated with adoption and implementation of structural adjustment policies (SAPs). Structural adjustment policies and programmes in trend during this period had highly pronounced adverse effects on the Universal Primary Education(UPE) policy implementation (Galabawa, 2001). This was evident from the falling enrolment rates, low enrolment rates and high internal inefficiency. The era spanned the period between 1986 and 1994 can be described as the era of moving towards what Rhodes refers to as "minimal state"(Rhodes 1996:653). Minimal state redefines the extent and form of public intervention, capitalizing on the use of markets and quasi-markets to deliver 'public services' abiding to the key tenet of public spending cuts (Rhodes 1996), a move that was hierarchically imposed by the World Bank and IMF . By and large, governance approach was drastically changed into a market regulation mode embedding new concepts such as free choice, market-oriented schooling and cost efficiency. During this period, the size of government was reduced by extensive privatization of state-owned enterprises (SOEs) and layoff of civil servants. Government control loosened to the extent of jeopardizing the pace of pursuing Universal Primary Education (UPE) agenda. The market mode of governance is also blamed for promoting externalities and socio-economic inequality in the country.

\subsection{Networks mode of governance}

Governance networks are conceptualized as pluricentric modes of governance, as opposed to the multicentric (market) and unicentric/hierarchical (state) forms of governance. According to Rhodes (2000), Networks are considered to be self-organizing, free from much government steering, thus are more autonomous approaches to governance. They are characterized by an exchange of resources and negotiations, and by game-like interactions are propped up on 'trust and regulated by rules of the game negotiated and agreed by network participants' (Rhodes 2000: 61). The importance of governance networks is connected to the fact that they provide 'a specific kind of weak institutional ties between institutions that are established on strong ties'. Governance networks are commended for their ability to provide flexible coordination between different actors in the present era of 'fragmented political systems'(Sørensen, 2011:3). They are argued to be highly flexible in terms of order, more open in terms of entry and exit; participatory in terms of actor involvement in decision making and network activities. However, due to the fact that decision making process in governance networks takes the form of deliberation and bargaining to consensus decisions through some means or another, it is associated with lack of speed in deciding and often results in poor decisions (Peters, 2011). In addition, democratic control and accountability of the actors is weak and problematic due to the fact that networks develop by default and that network participants are not elected but (self-) appointed into the network (Sørensen \& Torfing, 2009).

Pluralist (networks) mode of governance in Tanzanian primary education sub-sector is seen in the period spanning from 1995 to date. Throughout this period of about two decades, the 
government of Tanzania has given great prominence to the introduction of reforms aimed at increasing the effectiveness and efficiency in the way public services are provided (Galabawa, 2001; Mushi, 2006). With these reforms, the creation of true collaboration between the state and the other education providers including private persons by encouraging them to establish and manage schools and other training institutions has become the key feature of this era. There is increased co-operation with the private sector in the provision of education, including such proactive initiatives as the training teachers and land allocation for building schools (URT, 2001). Citizen participation in administrative deliberative processes has become a cornerstone to better public service delivery. This period of government which spans from 1995/96 to date, can be described as the era of "income and non-income poverty collective national thought" efforts are geared towards addressing both income and non-income poverty so as to build capacity for provision and consumption of better social services (Galabawa, 2001).

\section{Features and challenges in the governance of primary education}

Governance of the primary education sector in Tanzania has undergone substantial transformations along with the major administrative, economic and political reforms that took place in the country from the 1970s. During the period of state control (1970s to the mid1980s), the state was the key player in all socio-economic development initiatives. This affected all service provision sectors including the primary education sub-sector under the UPE initiative (Kuder, 2005). Primary schools were centrally controlled and managed by the Ministry of Education through appointed regional and district education officers. The place of non-state actors in governance of education was extremely minimal. This state-centric mode of the developmentalist ideology (developmentalism) led to the weakening of local government institutions in favor of the central ones. In 1972, the government embarked on a decentralization programme which abolished local governments and the country went without local councils. Although they were re-established in 1982, local councils became mere agents (field offices) of the central government, hence disempowering the people at the grassroots. Communities were completely left out in the determination of important issues such as school expenditure, procurement of supplies, management and the general development of the schooling environment of local primary schools, which led to lack of local ownership and accountability (Mushi, 2006; Masue, 2014).

During the pluralist era Tanzania started to implement extensive educational reforms under decentralization-by-devolution strategy in the mid-1990s which was embedded in the general government decentralization framework called the Local Government Reform Programme (URT 2007) to promote community participation. Thus, the delivery of the primary education has become the most important responsibility of local governments. 


\section{MInstitute Macrothink $^{\text {Int }}$}

Table 3: A summary of the key trends, overarching features and pitfalls

\begin{tabular}{|c|c|c|c|}
\hline Trend & Mode of governance & Key features & Pitfalls \\
\hline $\begin{array}{l}\text { The expansionary } \\
\text { collective national } \\
\text { thought era (1974- 1985) }\end{array}$ & State control & $\begin{array}{l}\text {-Centralized institutions, no } \\
\text { participation of private actors, } \\
\text { NGOs/CSOs \& citizens at large } \\
\text {-Big government with } \\
\text { excessively high spending } \\
\text {-High enrolment rates } \\
\text {-state was the key player in } \\
\text { education delivery }\end{array}$ & $\begin{array}{l}\text { - Poor } \\
\text { implementation } \\
\text { capability due to } \\
\text { limited resources } \\
\text { - Poor education } \\
\text { infrastructure } \\
\text {-Internal } \\
\text { inefficiency }\end{array}$ \\
\hline $\begin{array}{l}\text { The growth of the } \\
\text { economy collective } \\
\text { national thought era } \\
\text { (1986 - 1994) }\end{array}$ & Market- regulated & $\begin{array}{l}\text { - Rolling back of state } \\
\text {-Cost-sharing } \\
\text {-Expansion of non-public } \\
\text { (private, religious) schools } \\
\text {-Hierarchical control by } \\
\text { multi-laterals (WB, IMF)- } \\
\text { conditionality }\end{array}$ & $\begin{array}{l}\text { - Exclusion of the } \\
\text { poor } \\
\text { - Serious drop in } \\
\text { enrolments } \\
\text { - High dropout rates } \\
\text { - Poor infrastructure }\end{array}$ \\
\hline $\begin{array}{l}\text { The income and } \\
\text { non-income poverty } \\
\text { collective national } \\
\text { thought (1995 to date) }\end{array}$ & $\begin{array}{l}\text { Pluralist (network) } \\
\text { governance }\end{array}$ & $\begin{array}{l}\text {-Multilevel governance: } \\
\text { implementation of international } \\
\text { development targets(IDTs) } \\
\text {-Implementation of PEDP } \\
\text { which was mainly funded by } \\
\text { WB and donors } \\
\text {-Abolition of school fees } \\
\text {-more public schools were built } \\
\text { and old renovated }\end{array}$ & $\begin{array}{l}\text {-Aid dependency } \\
\text {-Inadequate and } \\
\text { delayed } \\
\text { disbursement } \\
\text { especially after the } \\
\text { end of PEDP I in } \\
2006 \\
\text { - Decrease in quality } \\
\text { of education }\end{array}$ \\
\hline
\end{tabular}

Source: Masue (2014:18)

\section{Concluding remarks}

In this paper, we have examined different trends in governance in Tanzania under state control, market regulation and pluralist (networks) systems and their implication for involvement of citizens in decision making. In the light of the analysis of the trends, there has been some incremental developments which can be seen in as far as involvement of citizens and their organizations in such areas as decision making in mobilization and use of human, material and financial resources for education service delivery.

However both multilevel and local governance modes have experienced a significant level of hierarchical control. In particular, the SAPs of the 1980s and the National Development Targets (NDTs) developed in the light of the International Development Targets (IDTs) have been hierarchically imposed, making the aid and development agencies function collectively and increasingly as a centralized global institution of aid governance (Kuder, 2005). At the domestic level, the civic groups and user committees formed in the localities to influence 
policies, plans and programmes are centrally initiated still face hierarchical control by the government through mandates and incentives and funding mechanisms). These are, of course, some indications that state-society actor networks in governance of primary education have improved, and the collaboration between these actors and the state has increased. However, it has been noted that control by the state organs (ministry, districts/municipalities, ward and village councils) over the actor behavior in terms of the overall education delivery process is still dominant. For example, school committees which have been assigned the responsibility of overseeing operational and strategic issues in their local schools are to a large extent constrained with bureaucratic control exercised District/Municipal authorities regarding important issues such as the procurement of school facilities, disciplinary control over the teachers and the like. This leads us to the conclusion that the shift from state control to network governance in the Tanzanian primary education has not sufficiently led to empowerment of the actors at the grassroots levels. This situation therefore calls for the state to willingly seek for a radical change from hierarchical control to real local empowerment

\section{References}

Agrawal, A., \& Lemos, M. C. (2007). A greener revolution in the making?: environmental governance in the 21st century. Environment: Science and Policy for Sustainable Development, 49(5), 36-45.

Ansell, C., \& Gash, A. (2008). Collaborative governance in theory and practice. Journal of public administration research and theory, 18(4), 543-571.

Baganda, E. (2008). Decentralisation and primary education in Tanzania: what are the contemporary successes and challenges?(Master Thesis).University of Oslo, Oslo.

Bell, S., \& Hindmoor, A. (2011). Governance without Government? The case of the forest stewardship council. Public administration, 90(1), 144-159.

Blanco, I., Lowndes, V. \& Pratchett, L. (2011). Policy Networks and Governance Networks: Towards Greater Conceptual Clarity. Political Studies Review, 9(3), 297-308.

Börzel, T. (1997). What's so special about policy networks? An exploration of the concept and its usefulness in studying European governance. European Integration online Papers (EIoP), 1(16).

Davidson, E. (2004). The progress of the primary education development plan (PEDP) in Tanzania: 2002-2004. Dar Es Salaam: Tanzania: HakiElimu.

Dawes, S. S., Cresswell, A. M., \& Pardo, T. A. (2009). From "need to know" to "need to share": Tangled problems, information boundaries, and the building of public sector knowledge networks. Public Administration Review, 69(3), 392-402.

Emerson, K., Nabatchi, T. \& Balogh, S. (2012). An integrative framework for collaborative governance. Journal of public administration research and theory, 22(1), 1-29.

Galabawa, C. (2001). Developments and issues regarding universal primary education (UPE) 
in Tanzania. Reaching Out, Reaching All, 49.

Hoberecht, S., Joseph, B.,Spencer, J. \& Southern, N. (2011). Inter-Organizational Networks. OD and Sustainability, 43(4), 23.

Huppé, G. A., Creech, H. \& Knoblauch, D. (2012). The frontiers of networked governance: http://www.ecologic.eu/files/attachments/Publications/2012/frontiers_networked_gov.pdf Accessed on 17.12.2012.

Isett, K. R., Mergel, I.A.,LeRoux, K.,Mischen, P.A.\& Rethemeyer, R.K. (2011). Networks in public administration scholarship: Understanding where we are and where we need to go. Journal of public administration research and theory, 21(suppl 1), i157-i173.

Jacobsen, D. I. (2012) The impact of governing networks - the role of context, organizing and trust: ISL working paper Vol. 1 Kristiansand Department of Political Science and Management, University of Agder, at http://brage.bibsys.no/hia/bitstream/URN:NBN:no-bibsys_brage_28615/1/ISLWP2012-1.pdf accessed on 30.12.2012.

Jessop, B. (2000). Globalisering og interaktiv styring. Roskilde Universitetsforlag, Frederiksberg.

Jessop, B. (2002). The rise of governance and the risks of failure: the case of economic development. International social science journal, 50(155), 29-45.

Kang, S. H. (2012). Transformation of Global Governance. http://www.eai.or.kr/data/bbs/kor_report/epik2012_j4.pdf, Accessed on 29.12.2012.

Kersbergen, K., \& Waarden, F. (2004). 'Governance'as a bridge between disciplines: Cross-disciplinary inspiration regarding shifts in governance and problems of governability, accountability and legitimacy. European Journal of Political Research, 43(2), 143-171.

Klijn, E.-H. (2008). Governance and Governance Networks in Europe. Public Management Review 10, 505-525.

Klijn, E. H., Edelenbos, J. \& Steijn, B. (2010). Trust in Governance Networks Its Impacts on Outcomes. Administration \& Society, 42(2), 193-221.

Klijn, E. H., Kickert, W.J.M. \& Koppenjan, J.F.M. (1997). Managing complex networks: strategies for the public sector: Sage Publications Limited.

Koliba, C. J., Mills, R. M., \& Zia, A. (2011). Accountability in governance networks: an assessment of public, private, and nonprofit emergency management practices following hurricane Katrina. Public Administration Review, 71(2), 210-220.

Kooiman, J. (2003). Governing as governance: Sage Publications Limited.

Kotz, D. M. (2009). The financial and economic crisis of 2008: A systemic crisis of neoliberal capitalism. Review of Radical Political Economics, 41(3), 305-317.

Kuder, J. (2005). UPE in Tanzania: SWAP-ing quality for quantity-again? Globalisation, 
Societies and Education, 3(2), 165-181.

Lavenex, S., \& Schimmelfennig, F. (2009). EU rules beyond EU borders: theorizing external governance in European politics. Journal of European Public Policy, 16(6), 791-812.

MacLeod, M., \& Park, J. (2011). Financial activism and global climate change: The rise of investor-driven governance networks. Global Environmental Politics, 11(2), 54-74.

Mandell, M. P., \& Keast, R. (2008). Evaluating the effectiveness of interorganizational relations through networks. Public Management Review, 10(6), 715-731.

Marsh, D., \& Rhodes, R. A. W. (1992). Policy networks in British government: Clarendon Press.

Masue, O. S. (2014). Empowerment of School Committees and Parents in Tanzania: Delineating Existence of Opportunity, Its Use and Impact on School Decisions.(PhD Thesis). University of Bergen, Bergen.

Mayntz, R. (2003). From government to governance: Political steering in modern societies. IOEW Summer Academy on IPP, Würzburg, September 7-11, 2003. http://www.ioew.de/fileadmin/user_upload/DOKUMENTE/Veranstaltungen/2003/CVMayntz. pdf, Accessed on 30.12.2012.

Mbilinyi, M. (2003). Equity, justice and transformation in education: The challenge of Mwalimu Julius Nyerere today. Dar es Salaam, HakiElimu.

Mmari, D. (2005). Decentralization for Service Delivery in Tanzania. Paper presented at the A paper presented by DMS Mmari, Permanent Secretary, President's Office, Regional Administration and Local Government, United Republic of Tanzania, at the conference on Building Capacity for the Education Sector in Africa, Oslo, Norway.

Mushi, D. P. (2006). Review of Experience with Direct Support to Schools in Tanzania.

Netter, J., \& Megginson, W. (2001). From state to market: A survey of empirical studies on privatization. Journal of economic literature, 39(2).

Newig, J., Günther, D. \& Pahl-Wostl, C. (2010). Synapses in the network: learning in governance networks in the context of environmental management. Ecology and Society, 15(4), 24.

Nyerere, J. K. (1967). Education for Self-Reliance Ujamaa Essays on Socialism. Dar es Salaam: Oxford University Press.

O'Toole, L. J. (2000). Research on policy implementation: Assessment and prospects. Journal of public administration research and theory, 10(2), 263-288.

O'Leary, R., Gerard, C. \& Bingham, L.B. (2006). Introduction to the symposium on collaborative public management. Public Administration Review, 66(s1), 6-9.

Orton, J. D., \& Weick, K. E. (1990). Loosely coupled systems: A reconceptualization. Academy of management review, 203-223. 


\section{Macrothink}

Journal of Public Administration and Governance ISSN 2161-7104 2015, Vol. 5, No. 1

Pal, L. A. (2012). Frontiers of Governance: The OECD and Global Public Management Reform: Palgrave Macmillan.

Peters, B. G. (2011). Governance as political theory. Critical policy studies, 5(1), 63-72.

Peters, B. G., \& Pierre, J. (1998). Governance without government? Rethinking public administration. Journal of public administration research and theory, 8(2), 223-243.

Pinelle, D., \& Gutwin, C. (2005). A groupware design framework for loosely coupled workgroups. Paper presented at the ECSCW 2005.

Provan, K. G., \& Kenis, P. (2008). Modes of network governance: Structure, management, and effectiveness. Journal of public administration research and theory, 18(2), 229-252.

Quibria, M. (2006). Does governance matter? Yes, no or maybe: Some evidence from developing Asia. Kyklos, 59(1), 99-114.

Rhodes, R. A. W. (1996). The new governance: governing without government1. Political studies, 44(4), 652-667.

Rhodes, R. A. W. (1997). Understanding governance: Policy networks, governance, reflexivity and accountability: Open University Press.

Rhodes, R. A. W. (2000). Governance and public administration. In J. Pierre (Ed.), Debating governance:Authority, steering and democracy. Oxford: Oxford University Press.

Scharpf, F. W. (1994). Games Real Actors Could Play. Positive and Negative Coordination in Embedded Negotiations. Journal of Theoretical Politics, 6(1), 27-53.

Sørensen, E. (2005). The democratic problems and potentials of network governance. European Political Science, 4(3), 348-357.

Sørensen, E. (2011). Enhancing democracy through inter-demos governance networks. at http://www.nccr-democracy.unizh.ch/publications/workingpaper/pdf/WP51.pdf, Accessed on 30.12.2012.

Sørensen, E., \& Torfing, J. (2004). Making governance networks democratic Centre for Democratic Network Governance, 2004 :1. Roskilde University, . Retrieved from

Sørensen, E., \& Torfing, J. (2005). The democratic anchorage of governance networks. Scandinavian political studies, 28(3), 195-218.

Sørensen, E., \& Torfing, J. (2007). Theoretical approaches to metagovernance. Theories of democratic network governance, 169-182.

Sørensen, E., \& Torfing, J. (2009). Making governance networks effective and democratic through metagovernance. Public administration, 87(2), 234-258.

Tengku-Hamzah, T., \& Adeline, A. (2011). Making Sense of Environmental Governance: A Study of E-waste in Malaysia. Durham University.

Torfing, J. (2006). Governance Networks and their Democratic Anchorage. Paper presented 
at the New spaces of European Governance, Vienna, Austria.

Tsai, W. (2001). Knowledge transfer in intraorganizational networks: effects of network position and absorptive capacity on business unit innovation and performance. Academy of Management Journal, 44(5), 996-1004.

URT. (2001). Basic Education Master Plan (BEMP). Dar-es-Salaam:Ministry of Education and Culture. 